\title{
Super-Positioning of Voltage Sources for Fast Assessment of Wide-Area Thévenin Equivalents
}

Møller, Jakob Glarbo; Jóhannsson, Hjörtur; Østergaard, Jacob

Published in:

Proceedings of the 2018 IEEE PES General Meeting

Link to article, DOI:

10.1109/PESGM.2018.8585962

Publication date:

2018

Document Version

Peer reviewed version

Link back to DTU Orbit

Citation (APA):

Møller, J. G., Jóhannsson, H., \& Østergaard, J. (2018). Super-Positioning of Voltage Sources for Fast

Assessment of Wide-Area Thévenin Equivalents. In Proceedings of the 2018 IEEE PES General Meeting IEEE. https://doi.org/10.1109/PESGM.2018.8585962

\section{General rights}

Copyright and moral rights for the publications made accessible in the public portal are retained by the authors and/or other copyright owners and it is a condition of accessing publications that users recognise and abide by the legal requirements associated with these rights.

- Users may download and print one copy of any publication from the public portal for the purpose of private study or research.

- You may not further distribute the material or use it for any profit-making activity or commercial gain

- You may freely distribute the URL identifying the publication in the public portal 


\section{Super-Positioning of Voltage Sources for Fast Assessment of Wide-Area Thévenin Equivalents}

Jakob Møller ${ }^{1}$, Hjörtur Jóhannsson ${ }^{1}$, Jacob Østergaard ${ }^{1}$

${ }^{1}$ Elektro, Technical University of Denmark

A method for superimposing voltage sources is sought optimized by using a sparse triangular solver and multiprocessing. A revision to the method is suggested which exploits Schur's complement of the network admittance matrix and optimal re-use of computations. The algorithm is implemented and parallelized for shared memory multiprocessing. The proposed algorithm is tested on a collection of large test systems and performance is found to be significantly better than the reference method. The algorithm will thereby facilitate a speed-up of methods relying on Thévenin equivalent representation such as the Thévenin equivalent method for contingency assessment. 